\title{
Monetary Policy in Argentina from the Inflation of the 1970s to the Default of the New Millennium
}

\author{
Vittoria Ferrandino \\ University of Sannio, Benevento, Italy \\ Valentina Sgro \\ University of Sannio, Benevento, Italy
}

\begin{abstract}
Since the end of World War II, Argentina has been through an uninterrupted series of financial/fiscal and monetary crises that have gradually eroded the credibility of the economic institutions of the country. In the period from 1970 to 1990 alone, the Argentine economy experienced seven currency crises and three banking crises. The main objective of this contribution is to investigate the reasons for economic policy choices that, since the military dictatorship of Colonel Perón, have led the country to default, causing unemployment, the run on banks, popular uprising. ${ }^{1}$
\end{abstract}

Keywords: Monetary policy, Financial Crisis, Argentina.

JEL Classification: N16, N26, N46.

\section{Introduction}

Argentina is a geographically very varied country and it is rich in terms of natural resources. It is a presidential federal republic: its federal institutional framework is one of the major factors of its uncontrolled public spending, which is one of the structural problems of the Argentine economy. The history of Argentina is typical of South American countries, characterized by very fragile democracies alternating with periods of military dictatorship. Therefore, those who are interested in studying South American economic situation may want to investigate the issues related to the economic policies of its governments.

This paper, through the study of the literature sources produced on this topic, aims to investigate the reasons behind the political and economic decisions taken by Argentine governments in history, illustrating the different consequences and trying to highlight what kind of alternative strategies could have been adopted. In fact, these considerations could be useful for those who may want to study in deep the issues relating to economic crises in countries with unstable economies, such as Argentina.

The last regime that began in 1976 and ended with the Falklands War of 1982, was the most cruel and bloodthirsty: another key to understanding the Argentine crisis is the lack of a real

\footnotetext{
${ }^{1}$ Even though the two authors share the article's setting, please note that paragraphs 1,2 and 3 are by Valentina Sgro and paragraphs 4, 5 and the introduction are by Vittoria Ferrandino.
} 
breaking point between the politicians of today and the military class. That fact, combined with the serious complicity of President Menem in indulging corrupt activity led to a moral crisis in the country, which caused the spread of widespread corruption.

The Nineties were the years of Menem and the Convertibility Plan. In Argentina a currency board was established, the financial system was restored, inflation dropped sharply, trade was encouraged, public companies were privatized. The humus of the economic crisis was exactly this. The federal budget was based on non-recurring revenue, while $50 \%$ of the outputs were dependent on the provinces (the first structural problem); moreover, Argentina, did not have an independent monetary policy and was necessarily affected by that of the US. The consequence of not being able to sustain its performance was the overvaluation of the real exchange rate (the second structural problem), that, in a rigid labor market like Argentina, pushed the unemployment rate to $22 \%$. The third and last structural problem was the recurrence of repression-loosening cycles of the Argentine economy, which had occurred even in the case of the convertibility plan. After an unusually long consumption boom, the distortions created by the fixed exchange rate unleashed a destructive effect in proportion to the duration of the stabilization program.

Also important were the effects on the Argentine economy of the international crises such as the Mexican crisis and the Tequila effect, the Asian crisis, the Russian crisis and the Brazilian crisis.

The Mexican crisis allowed the restructuring of the Argentine financial system, and the strength of this system enabled the country to survive the international crises of the following years. After the second boom of 1996-1997, the Asian crisis and the Russian crisis were overcome brilliantly, with the performance of Argentine bonds much higher than that of other South American countries. This, however, constituted a wake-up call that was not understood by the Argentine authorities: the overvaluation of the real exchange rate, which in early 1999 also caused the collapse of the Brazilian real, was in fact undervalued and Argentina entered a long recession phase.

The administration of De la Rua did not have a united coalition behind it, indeed problems were exacerbated by the Peronists' opposition who constituted the majority of the provincial governors. However, thanks to the support of the International Monetary Fund and a solid and unchanged financial system with a wide consensus as regards the Convertibility Plan, the Government of Argentina overcame the crisis of late 2000. The following year, Domingo Cavallo returned but, however, he did not have the political courage to leave the regime which he had established in 1991. He passed a series of restrictive maneuvers of fiscal policy, which aggravated the recession leading to the «state of siege». Cavallo resigned, De la Rua escaped together with his family, the Peronists again returned to power. This marked the end of the Convertibility Plan, the parity 1: 1 with the dollar, and it led to the declaration of insolvency.

Was it possible to find a «softer» exit strategy, perhaps abandoning the currency board before 2002? Would it have been better if the Duhalde presidency, that followed in 2002, had chosen a different monetary policy, perhaps an official dollarization or a flexible exchange rate, instead of opting for the "peso» devaluation? These are the questions which one can try to answer, through a careful reconstruction of the main events of the Argentine economy. 


\section{The Argentine economy from Peronism to the Revolución Libertadora}

After the conclusion of World War II, Argentina was in a flourishing economic situation. The supply of food to the warring countries had allowed the country to accumulate large reserves in foreign currency, an activity expected to grow thanks to the increased safety of sea transport and the consequent expansion of international trade.

In 1946, Colonel Juan Perón was elected President thanks to his sensitive policy regarding workers' living conditions. His popularity and influence grew with the support of his second wife Eva Duarte de Perón who created a system of national assistance and obtained substantial wage increases for the unions, getting their support.

Argentina took advantage of the special postwar situation and until 1948 enjoyed a period of great economic prosperity that allowed Perón to carry out a policy of economic reforms: nationalization of the Central Bank, repayment of debt, planning of the first five-year plan. However, the well-being provided by this program was short-lived and the regime began to be unable to respond effectively to the worsening economic situation, characterized by an export crisis and the beginning of the trade balance deficit.

In fact, the favorable external conjuncture in which the Peronist State took its first steps began to reverse towards 1949, when the huge exchange reserves accumulated during the war began to run out. After four consecutive years of surplus, the trade balance had a deficit of $\$ 160$ million, mainly due to the return to normality in agricultural and meat prices, causing a deterioration in terms of trade of Argentine goods; also the development of light industry made the country increasingly dependent on raw materials and foreign semi-processed products, determining the rise of production costs and consumer prices of products. The inflation resurgence, from $13 \%$ in 1947 to $29 \%$ in 1949, and the increasing numbers of unemployed were the ultimate consequences of this process.

The economic situation of the period 1949-1955 can be divided into three phases: the first two years of transition (1949-1950), during which limitations on public expenditure were introduced and an attempt was made to control wage growth; a period of violent demonetization, strong imbalances in accounts with foreigner countries and a deepening of the recession (1951-1952). Finally, a period of consolidation, first cautious and then more and more determined, with the introduction of measures to promote the availability of capital and hard currency in order to revive the economy. ${ }^{1}$

In January 1953 the government began its second five-years plan, this time focusing on increasing agricultural production. In the following months Argentina signed important trade and economic agreements with several countries (including UK, the Soviet Union and Chile), making the trade balance active again while the Argentine currency, however, continued to suffer a sharp devaluation.

On June 16th 1955 some dissidents of the Argentine Air Force started an anti-peronism revolt, which failed because the army decided to remain loyal to the government. The event happened again three months later, but this time the army involvement showed a wider base of support, so that, after three days of civil war (with the death of about 4,000 people), Perón was forced to resign and take refuge in exile first in Paraguay, then in Spain. Meanwhile, on September 20,

${ }^{1}$ F. Silvestri, L'Argentina da Perón a Cavallo (1945-2003). Storia economica dell'Argentina dal dopoguerra a oggi, Bologna, 2004, pag. 21. 
Major Eduardo Lonardi assumed the duties of interim president of Argentina, promising the prompt restoration of a democratic regime by starting the Revolución Libertadora. However, after a brief internal struggle, the vision of the more strongly anti-peronist group prevailed in the army and on November $13^{\text {th }}$ of the same year, Lonardi was replaced by General Pedro Eugenio Aramburu, who was closer to liberal sectors.

Between the social forces driving the ongoing transformation, which however had not yet sufficiently clearly defined its objectives and resources, and those that were the basis of Peronism, organized and able to put up a strong resistance, the so-called empate was put in place which lasted until the Seventies, a kind of a break-even situation in which none of the social actors could prevail over the other, so as to direct the course of Argentine politics according to their own perception of the problems ${ }^{1}$.

In order to rebalance the external accounts and help the primary sector exporters, Argentina proceeded with the devaluation of the Peso. The exchange rate for export was devalued in real terms by $100 \%$ (152\% nominal), and that for importation by $75 \%$ (114\% nominal $)^{2}$. The measure, however, was adopted in a context of low market prices and, therefore, the final outcome on the expansion of exports resulted lower than expected. At the same time, trade liberalization implied a significant increase in demand for foreign goods and, during the same period, the rate of interchange of tradable products from Argentina recorded its lowest value since 1933. This conjuncture determined as its final consequences, between 1955 and 1958, the accumulation of an uninterrupted sequence of a balance of payments deficit, the steady erosion of foreign reserves and the increase of foreign debt.

In 1961 there was a considerable economic recovery and the GDP, driven by strong and diversified foreign investment, achieved a growth rate of 7\%, which was then repeated a year later, and inflation on an annual basis went from 127\% in June 1959 to 9.5\% in April 1961. However, there were still violent but short and regular fluctuations which became a negative phenomenon typical of the Argentine economy. Furthermore, the level of domestic absorption driven by investment demand, machinery and technology stayed higher than GDP growth, leading to a further deterioration of the balance of payments. ${ }^{3}$

The period between the election of Frondizi (1958) to the fall of Illia (1966) was characterized by a very negative balance and, despite the efforts of successive governments, the Argentine economy was not able to solve its problems of cyclicality and dependence on foreign countries. Peronism was deeply rooted in the country, keeping its sancta sanctorum in the labor union, which was also characterized by a more and more corporative, top-down and anti-democratic drift.

\section{Military dictatorship and its economic legacy}

By the 1970s, many Argentines with warm memories of postwar prosperity were clamoring for the military to allow Peron to return home. The generals relented, and in 1973 Peron assumed the presidency once again hoping to revitalize the Argentine economy. But he was

\footnotetext{
1 J.C. Portantiero, Clases dominantes y crisis politica en la Argentina actual, Buenos Aires, 2003.

2 C. Diaz Alejandro, Tipo de cambio y términos del intercambio en la Républica Argentina (1913-1976),

Work Documents series N. 22, Centro de Estudios Macroeconómicos de Argentina, 1981.

3 F. Silvestri, L'Argentina da Perón a Cavallo (1945-2003). Storia economica dell'Argentina dal dopoguerra a oggi, cit., pag. 38.
} 
unable to heal either the economy or the increasingly violent fissures in Argentine society, and Peron died of heart failure just a year later. His wife, Isabel Martínez de Perón, succeeded him in power and had to face an administration mined with economic problems, conflicts within the party and a growing terrorism practiced by insurgents and paramilitary movements. Inflation became ever greater and the economy of the country was threatened by paralysis of investments, the suspension of meat exports to Europe and the beginning of a major worsening of public debt. A solution of a monetarist type was unsuccessfully attempted by the Minister Alfredo Gomez Morales, causing rather more a process of stagflation. The coexistence of urban guerrillas, an organized working class and a weak government with neither political nor economic goals, caused the Armed Forces and the upper classes to install, once again, their form of order in Argentina. The aim of the alliance was to subordinate and control the working class, to undermine its capacity to organize itself as a class and to express itself politically. This disciplinamiento social was achieved by both state terrorism and a structural economic reform ${ }^{1}$. Thus, on March 24th 1976 , a new military coup rose to power led by General Jorge Rafael Videla who imposed martial law. Videla came to power with greater strength and freedom of maneuver than any of his military predecessors. With the collapse of Peronism, the disruption of the unions, and the population at large prostrated by strikes, lockouts, inflation and terror, only the guerrillas offered organized resistance ${ }^{2}$. Thousands of opponents of the regime were illegally imprisoned, tortured and executed. The so-called Dirty War reached its peak in those years and it was characterized by a massive violation of human and civil rights by using methods such as the deprivation of liberty without legal proceedings, detention in secret places controlled by the armed forces, torture, murders and disappearances; during this period, in addition to the thousands of people imprisoned, there were about 2.300 political killings and about 30.000 people disappeared (desaparecidos), 9.000 of them were subsequently officially recognized by the Comisión Nacional sobre la Desaparición de Personas.

For some five years after the coup economic management was entrusted to José A. Martínez de Hoz, a member of one of the great landed families and a prominent figure in banking. He immediately attacked hyperinflation and the steep balance-of-payments deficit with an onslaught on consumption and wages. With Martínez de Hoz a commitment came not only to restore order in the economy but also to change and reconstruct it. The minister and the leading members of his team, all extreme market economists, attacked the heavy concentration of economic power in the state and pushed for its dismantlement. They wanted a prolonged attack on inflation by monetary controls. In the event Martínez de Hoz's program was applied only in part, mainly to accomplish short-term recovery, by 1978 it was losing momentum and the 1978 crisis was the only one in which a fall in GDP was intentionally implemented by the government through a monetary contraction that was meant to stop inflation ${ }^{3}$.

The results of Martínez de Hoz's economic policy were that between 1980 and 1981 the rate of the GDP went from 0.7 to -6.2 , per capita GDP from - 0.9 to -7.7 , and gross national income from 1.8 to -7.0 . These modifications were concentrated in one year as a result of the

\footnotetext{
1 L. Tedesco, Democracy in Argentina. Hope and disillusion., New York, 1999, pag. 23.

2 D. Rock, Argentina 1516 - 1987. From Spanish Colonization to Alfonsín, Los Angeles, 1985, pag. 367.

${ }^{3}$ A. Sturzenegger - R.Moya, Economic cycles, in G. Della Paolera - A.M. Taylor (edited by), A new economic history of Argentina, Cambridge, 2003, pag. 95.
} 
economic policy applied in the previous four years ${ }^{1}$. The implementation of Martínez de Hoz's economic policy weakened the already vulnerable Argentinian economy and the nation fell gradually into a state of anarchy, an economic and political turmoil that led, in September 1982 , to the verge of bankruptcy, burdened by a public debt of almost $20 \%$ of GDP and an intractable dimension of foreign debt.

In 1982, the military launched an invasion of the Falkland Islands, a British colony claimed by Argentina and called the Malvinas by the South American country. Britain retaliated, and Argentina lost the ensuing brief, but bitter war. The army was accused of using the conflict to distract people from the economic woes fueling political discontent. The Malvinas-Falklands War marked the end of the military regime established seven years before and the return of governments that were elected in a democratic way: if such an event involved a partial attenuation of the drama of political relations, the same could not be said for the economic situation, which continued to be rather worrying; the teams that led the country the following years saw most of their efforts absorbed in an attempt to regain control of the macro-economic aggregates. Certainly the most problematic of these was the inflation rate, now firmly above $100 \%$ per annum.

\section{Back to democracy and origin the of Menemism.}

During the National Reorganization Process, from 1976 to 1983, a large debt was accumulated to finance several projects, such as the Falklands War and the state appropriation of private debt. At the end of the military government Argentine companies were severely affected and unemployment, calculated at $18 \%$ (even if the official bodies claimed at $5 \%$ ) sharpened the economic difficulties.

In October 1983, in a situation of extreme economic crisis, the country held, for the first time in ten years, a democratic presidential election, electing the candidate of the Radical Party Raúl Alfonsín. However, beyond the enthusiasm for a return to democracy, Alfonsín had to face a dire economic situation, which was the result of mistakes of the past (such as the model of import substitution, which had created a production system unsuitable for competing internationally) but also of choices made by others, such as the Reagan monetary policy and its resulting relentless growth of international interest rates and the explosion of foreign debt in Latin American countries².

During its first year in office, the democratic government was not in a position to change the situation drastically. The new authorities were faced with two main issues: firstly, the need to look for an efficient and non-conflicting way to satisfy the demands of a population that had experienced a 15\% decline in its per capita income over a five-years period; and, secondly, the need of reaching an agreement with foreign creditors to cope with arrears that had been accruing since 1982 as well as to meet future maturities that were closing in.

Tab. 1 - Argentina's external debt (millions of US dollars) ${ }^{a}$

\begin{tabular}{cccc}
\hline Period & Public sector & Private sector & Total \\
\hline 1975 & 4.021 & 3.854 & 7.875 \\
1976 & 5.189 & 3.091 & 8.280
\end{tabular}

${ }^{1}$ L. Tedesco, Democracy in Argentina. Hope and disillusion., cit., pag. 47.

2 S. Gatto, America Latina: il decennio cruciale (cronache d'estremo occidente), Venezia, 2004, pag. 65. 


$\begin{array}{cccc}1977 & 6.044 & 3.635 & 9.679 \\ 1978 & 8.357 & 4.139 & 12.496 \\ 1979 & 9.960 & 9.074 & 19.034 \\ 1980 & 14.459 & 12.703 & 27.162 \\ 1981 & 20.024 & 15.647 & 35.671 \\ 1982 & 28.616 & 15.018 & 43.634 \\ 1983 & 31.709 & 13.360 & 45.069 \\ 1984^{b} & 36.139 & 10.764 & 46.903 \\ 1985^{b} & 39.868 & 8.444 & 48.312 \\ 1986^{b} & 42.039 & 7.099 & 49.138\end{array}$

Source: Banco Central de la Républica Argentina in AA.VV., Inflation stabilization. The experience of Israel, Argentina, Brazil, Bolivia and Mexico, Boston, 1988.

Until 1978 the foreign public debt excluded terms shorter than 180 days.

For 1984 and 1985 and for January to September 1986 the stocks are estimates based on the debt flows involved in the balance of payments. Non-dollar denominated obligation are calculated at the exchange rates of December 31st, 1983.

Therefore, an appropriate incomes policy and adequate negotiations on the external front were of utmost priority. The first issue was tackled by setting the rate of adjustment of prices and wages in an attempt to engineer a gradual slowdown of inflation. Nevertheless, shortly after these measures had been implemented, an increase in foodstuff prices (particularly beef) triggered inflation above anticipated levels. The attempt to index salaries on a monthly basis to preserve their purchasing power (as promised by the government during its electoral campaign) pushed the inflationary rate to a new higher monthly level. The second issue was addressed through a negotiation strategy that sought new maturity agreements directly with creditor banks and the Paris Club rather than through the implementation of a new IMF standby agreement ${ }^{1}$.

The project of the new government of Alfonsín included the stabilization of the Argentine economy and the creation of a new currency, the austral, the first currency in Argentina not to be called Peso. The introduction of the austral represented the origin of new loans and when the State became unable to pay interest on the debt, the confidence in the austral collapsed. Inflation, which had been maintained at monthly rates between 10 and $20 \%$, became uncontrolled. In July 1989, Argentina's inflation reached a monthly rate of $200 \%$, and a variation of $5.000 \%$ per year. It interested especially the middle class, plunging the country into shocking levels of relative poverty. During the presidency of Alfonsín, unemployment did not go up while real wages were halved and they reached their lowest level of the past 50 years. The popular uprisings of 1989 lead Alfonsín to resign five months before his mandate expired.

${ }^{1}$ AA.VV., Inflation stabilization. The experience of Israel, Argentina, Brazil, Bolivia and Mexico, cit., pag. 119. 
The new President Carlos Menem, a Peronist, adopted emergency economic measures. He began an economic austerity plan with several interventions of privatization of public companies, cuts in social spending, deregulation in different sectors and also focusing on the arrival of foreign capital. The aim of his policy was to privatize as much as possible in order to eliminate public spending and consequently to settle the foreign debt. He managed to bring inflation back to levels unimaginable a few years earlier but the reforms had also heavy social costs, leading to a sharp rise in unemployment and poverty and in the trade deficit and in 1990 the government shocked Argentines with the announcement that private savings accounts would be exchanged for government-issued ten-year bonds. The overall policy package caused a recession and it also led Argentina's hyperinflation to end ${ }^{1}$.

\section{Growth without industrialization ${ }^{2}$ : Argentina from the Eighties to the Nineties}

The belief that a country rich in natural resources (from the Pampas plains to mineral deposits) could grow relying only on the production of agricultural goods was the fundamental weakness of a model of economic development characterized by the volatility of commodity prices. Actually, from 1880 to 1983, Argentina had adopted three major models of development. The agro-exporter model (or granaderia), based on the export of meat and grain, that in a few decades had led the country into the international limelight, allowed the growth of the city-port and then of the commercial middle class. This model had started a modernization that was not linked to a process of industrialization alternative to land ownership, as had happened in Europe and the United States. The particular Argentine social stratification came from this model: the oligarchy of terratenientes, the professional and business urban middle class, the broad category of immigrants at the margins of the political system and, at the center, the army as the only national and technical body ${ }^{3}$. With the rise of colonel Perón, the Import substitution industrialization was consolidated, and it focused on the development of the internal market and industrialization mainly through the nationalization of companies and public services with foreign companies, as well as through redistributive measures aimed at transferring economic resources from the export sector to the industrial one. The following military dictatorship of General Videla (1976) was characterized, instead, by the adoption of a neoliberal economic model, proposed by Economy Minister Martínez de Hoz, which was based primarily on reducing the role of the state in the economy, the gradual opening up of the market and the elimination of public subsidies for internal consumption, as well as the liberalization of administrative controls on economic activities. Until 1978 there had been a recovery in production, especially of consumer durables and investment, but the attempt to reduce inflation with restrictive monetary policies had created an economic downturn, aggravated, in December of that year, by the decision to eliminate any customs protection, foretelling the currency devaluation and the liberalization of the capital market. The opening up of the internal market had exposed the Argentine enterprises to a strong international competitiveness, while internal growth in interest rates had generated high levels of debt. With the change of government of General Galtieri, in March

\footnotetext{
1 T. L. Edwards, Argentina. A global studies handbook, Santa Barbara, 2008, pag. 52.

2 About this, Giorgio Alberti wrote about «original sin» of modern Argentina, namely a modernization without industrialization (G. Alberti, F.M. Castiglione, P. Munini (1985), Politica Y ideologia en la industrializacion argentina, in «Boletin Informativo Technit», n. 239, pp. 7-20).

3 B. Kosacoff, Corporate Strategies under structural adjustment in Argentina, London, 2000, Macmillan Press, pag. 46.
} 
1981, the State agreed to cover the debt of private companies, guaranteeing it with the international debt, returning to strict protectionist measures and to the nationalization of the economy, while inflation continued to grow ${ }^{1}$. The democratic elections of 1983 represented an event of extraordinary importance and the new president Alfonsín had to deal with the crisis of external debt and a fiscal crisis of the state, in the presence of an unprecedented hyperinflation. The economic policies undertaken in Argentina between 1983 and 1999 had to pursue, then, the twofold objective of fighting inflation and of implementing measures of fiscal and monetary policy that would allow the country to create a virtuous circle of economic development, enabling the reduction of the huge foreign debt and the revival of the entire economy. The two most important and significant stabilization programs implemented in this period were the Austral Plan (1985) and the Plan of convertibility (1991)2, the latter developed by Economy Minister Domingo Felipe Cavallo. It was intended to get out of hyperinflation through the establishment of a currency board with the dollar, forcing the fixed parity 1 to 1 between peso and dollar. On the one hand, the Central Bank undertook to keep sufficient reserves and to protect the amount of circulating money. The monetary base should not have exceeded the reserves of the Central Bank, calculated at a rate of change of a peso for a dollar. The plan was that the monetary base could be increased only when the Central Bank had an adequate level of additional reserves and not when the public sector or the financial system required it. Stocks could be in the form of deposit or other debt instruments (Argentine government bonds or foreign governments bonds). On the other hand, the deficit could not be financed through loans from the Central Bank. The adopted convertibility regime functioned as a signal of stability for daily transactions and for the system of financial contracts, contributing to the stabilization of the financial market expectations ${ }^{3}$.

$90 \%$ of public enterprises identified for privatization in the period 1990-1998 were transferred to the private sector before the end of 1994. Among these were the National Company for oil exploitation (YPF), the national phone company (ENTEL), the Airline company Aerolinea Argentinas. As a result of these privatizations, the State cashed \$11.3 billion, plus $\$ 14.8$ billion taken away from their liabilities, leaving the foreign debt of the enterprise at the nominal value. At the same time, privatizations led to a reduction of public employees in state-owned enterprises from 347.240 units in 1989 to 66.731 in 1993, as a result of the redundancies ${ }^{4}$.

At the end of 1992, privatization led to transfers of over $\$ 16$ billion of asset value, only a small part of which consisting of actual revenue, because most of it resulted in transfer of debt of public enterprises to private. The total value of revenue came to 60 per cent for companies

1F. Silvestri, L'Argentina da Perón a Cavallo (1945-2003). Storia economica dell'Argentina dal dopoguerra a oggi, cit., pp. 38 et seq.; cfr. G. O’Donnel, El estrado burocratico autoritario, Buenos Aires, 1982, Ed. Belgrano.

2 Cf. P. Sylos Labini , El Plan Austral y la politica argentina: algunas reflexiones, Buenos Aires, Istituto Torcuato di Tella, Centro de Investigaciones Económicas; P. Bianchi, R. Sugden, J. R. Wilson, The crisis in industrial structure in Argentina: lessons for development policy and practice, $7^{\text {th }}$ Annual EUNIP (European Network of Industrial Policy), September, 18-20, 2003, Porto, Portugal.

3 M. Novaro, V. Palermo, Politica y poder en el governo de Mennen, Grupo editorial Norma Ensoyo. For more information about currency board, see also Hanke Steve H., Schule R K., Currency board for developing countries: A handbook, 2000.

${ }^{4}$ Cf. J.M. Ghio, S. Etchhemendy, The policy of administrative reform in Menem's Argentina, 1997, Universidad Torcuato di Tella. 
and foreign banks and the remaining part from national economic groups. Foreign companies in the area of Argentina were also allowed to turn foreign debt into capitalization of the local firm for over $\$ 600$ million$^{1}$. Most of the invested capital came from the United States, Spain and Italy and focused more on the service sector than on that of productive enterprises ${ }^{2}$.

In the meantime, the significant increase in liquidity in the system, due to massive inflows of foreign capital, and the stability provided by the convertibility plan favored the recovery of the intermediation function of the banking system. In particular small and medium-sized enterprises took advantage of it, while large companies relied on forms of financing, outside the domestic banking system, or on the capital market. The presence of foreign banks, characterized by larger dimensions than the national ones, and the Mexican crisis that broke out in 1994 led to a delicate and important process of restructuring of the whole banking system in Argentina, through the merger of provincial and local small banks, the substantial reduction of the public bank in the circuit of the banks on the national territory, the introduction of new prudential supervision rules that covered both the capital requirements and those relating to liquidity. From 1991 to 1999, the total number of banks operating in the country was reduced from 167 to $119^{3}$.

Economic growth during the Menem second term (1995-1999) was different from that of the early nineties. The economic expansion of the beginning of the decade had been triggered mainly by the success of the Convertibility Plan and, above all, by the high level of foreign investment. However, between 1995 and 1998, the international context changed; the crisis that invested the entire global financial system (such as the Mexican crisis in late 1994, the financial instability in the Southeast Asia countries in 1997, the Russian crisis of 1998 and that of Brazil in 1999) slowed the inflow of foreign capital to Argentina; interest rates, both active and passive, began to grow. Therefore, the anchoring of the peso to the dollar went from an element of economic stability and growth into a narrow bond for the Argentine economy. Between 1991 and 1997, GDP had risen by an average of 5.5\% per year, while inflation dropped from 170 to 1\%. Likewise investment had increased, since the rate of fixed investment at constant prices had increased from $17.3 \%$ of the year $1982-90$ to $25 \%$ in 1998 , with an average of $21 \%$ in the period 1991-1998. However, among the following excellent results recorded by GDP and investments, other variables marked values contrasting the good economic recovery. The unemployment rate, for example, had more than doubled, rising from

\footnotetext{
1 B. Kosacoff, El desafio de la competitividad. La industria argentina en trasformatcion, Buenos Aires, 1993, CEPAL/Alianza Editorial, pp. 260-269.

2 Cfr. Economic Commission for Latin America and the Caribbean (Eclac), Strategie per una migliore integrazione della politica globale, Santiago, 1994. The foreign capital entering the country as a result of privatization was not all of «lawful nature» and often was not even reinvested in the system, so it did not turn into new productive investments, and was not held as deposits inside the national banking system. In fact, capital was directly transferred to bank accounts of foreign banks, thereby generating a continuous escape of capital and a climate of considerable corruption. Corruption and capital flight abroad were among the reasons that some observers have pointed out as the collapse of the Argentine economy in 2000 (A. Infranca, Argentina, modello di neoliberismo, in «Critica marxista», nuova serie, $\mathrm{n}$. 3/4, may-august 2000; J. E. Stiglitz, Etica, politica economica e paesi in via di sviluppo, in L. Ornaghi, edited by, Globalizzazione: nuove ricchezze e nuove povertà, Milano, 2001, Vita e pensiero, pp. 123 et seq.).

3 Banco Central de la Repubblica Argentina, Bullettin of monetary and financial affaire, publications from the first trimester $1997 \mathrm{vol}$ III trimester 2003, data at 31st December of each year.
} 
$5.9 \%$ of the Eighties to $12,1 \%$ in the following ten years. In 1998, the unemployment value exceeded $15 \%{ }^{1}$. The Nineties also marked the growth of the external debt level, which increased from 61 to 154 billion dollars in the period 1991-20002.

\section{From the financial crisis to the defaults}

The effects of the Mexican crisis, the so-called Tequila effect, were also felt in Argentina, causing a brief economic recession ending in the second trimester of 1996. In December 1994, Mexico was forced to devalue its currency against the US dollar, because of the intense pressure on the exchange rate, not thus succeeding in refinancing the massive level of external debt denominated in dollars (the so-called Tesobonos). The effect of the maneuver in Argentina was soon to be felt, especially because of the Argentine peso being overvalued against the dollar. In a few days the Argentine stock market lost $17 \%$ and the price of the bond fell by $12 \%$. Between the end of 1994 and the first three months of 1995, deposits were reduced by $15 \%$ and banks were no longer able to grant new loans. The liquidity crisis caused a rise in interest rates, both active and passive, both in pesos and in dollars (loans in pesos increased from 7,46 to 8\%, those in dollars from 13,98 to 20,11\%). The Central Bank defended the change, causing an outflow of about a quarter of reserves between December 1994 and March of the following year (the reserves went down from 17.938 to 13.303 million pesos). The deposits, instead, were reduced from 46.521 to 39.663 million pesos ${ }^{3}$.

The real economy, because of the liquidity crisis and the increase in interest rates, entered a brief recession characterized by disinvestment, a fall in consumption and by the slowdown in economic activity, which had already ended by the second trimester of 1996, thanks to the restructuring of the banking system. The Monetary Authority of Argentina, in fact, succeeded in avoiding a financial crash, without leaving the fixed exchange rate regime. Through the actions taken, the compulsory reserves ratio on deposits in dollars and pesos was reduced in order to ease the pressure on banks; dollarization of deposits in pesos of commercial banks at the Central Bank was performed in order to restore confidence in the fixed parity between the peso and the dollar, thus reducing the incentive to devalue the monetary authority to reduce the real value of its debt; an emergency fund was established and it acquired a loans portfolio of banks in crisis; a deposit insurance fund was introduced. Furthermore in March 1995, the government obtained access to international credit for about $\$ 7$ billion, including a line of credit of about $\$ 1$ billion granted by the International Monetary Fund. The IMF was worried that a dangerous «domino effect» could be started in the global financial system. The entry of this foreign funding turned out vital to overcome the current crisis, because it represented for economic operators a strong signal of confidence in the good health of the Argentine economy. The Argentine financial system emerged strengthened from the Mexican crisis. In the period 1996-1997, the real economy grew overall by $13,6 \%$, while the unemployment rate fell to $13,7 \%$ from $16,6 \%$ two years before ${ }^{4}$.

The Asian crisis, which began with the devaluation of the Thai baht in July 1997, caused the increase of the yield spread of all emerging market stocks, dragging upward even the interest

\footnotetext{
${ }^{1}$ www.mecon.gov.ar (Argentine Ministry of Economy); cf. G. Kaminsky, S. Lizondo, C. Reinhart, Leading indicators of currency crisis, International Monetary Fund Staff Papers, 1998, vol. 45, n. 1.

2 Il Sole 24 ore, political, economic and financial daily newspaper founded in 1865, December 27th 2001.

3 Banco Central de la Repubblica Argentina, Bullettin of monetary and financial affaire, cit.

${ }^{4}$ www.mecon.gov.ar (Argentine Ministry of Economy).
} 
rates in Argentina. In Argentina, however, there was no rush to deposit money, but only a slight shift from deposits in peso to those in dollars. Therefore, the interest rates came back to a level which was slightly higher than the pre-crisis situation. Instead, the Russian crisis of 1998 and the Brazilian crisis one year later had devastating effects on the Argentine economy. For the first time since 1991, the value of Argentine exports was reduced by 12\%, in particular in regard to wheat, fruits, oil and meat. While Brazil decided to undock its currency from the dollar and let it float freely ${ }^{1}$, Argentina kept the fixed parity peso-dollar, causing a progressive loss of competitiveness of Argentine goods compared to those of its neighbor Brazil and a «substitution effect» with Brazilian products. The Brazilian crisis and the subsequent devaluation of $75 \%$ of the real accentuated the difficult economic situation in Argentina, causing a drastic reduction in GDP $(-3.4 \%)$ in $1999^{2}$. The currency board, and then the anchoring to the American currency (always stronger in the currency markets), involved a continuous appreciation of the real exchange rate of the actual peso, which corresponded to a continuous loss of competitiveness. Of course the appreciation of the real effective exchange rate was determined also by the strong appreciation of the bilateral real exchange against the Brazilian real, which caused a very negative effect on the credibility of the currency board; in fact, Brazil was the main outlet market for Argentine exports (almost a quarter of exports). There was an unprecedented boom in imports and a sharp slowdown in exports of manufactured goods from Argentina. The expectation of a devaluation decided by the authorities of Buenos Aires caused further capital outflows, it pushed up interest rates and encouraged the further decline of bank deposits in pesos in favor of those in dollars. Between the second half of 1998 and the end of 2001 the share of households' bank deposits denominated in dollars went from 55 to $71 \%$, continuing the process of dollarization of the Argentine financial system that had already been characterized by a strong increase of loans to enterprises denominated in dollars (from 41 to $58 \%$ of the total in only 5 years) in the early Nineties ${ }^{3}$.

The slowdown in growth in the second half of the Nineties, the significant appreciation of the dollar and the devaluation of the Brazilian real made the peso overvaluation problem increasingly pressing. Given that the currency board regime imposed a fixed exchange rate between dollar and peso, the adjustment process operated through an internal deflation, however, turned out to be long and difficult because of price rigidity ${ }^{4}$.

\footnotetext{
${ }^{1}$ Both Mexico and Brazil had anchored their currencies to the dollar, giving them a too high value: four to one for the Mexican «peso» and two to one for the Brazilian real, which was introduced in 1994 to replace the old «cruzeiro» totally devalued. The exchange ratios were too high and could not be sustained for a long time (E. De Simone, Storia economica dalla rivoluzione industriale alla rivoluzione informatica, Milano 2014, Franco Angeli, pp. 319-320).

2 Cf. M. Rapoport y collaboradores, Historia econòmica, pòlitica y social de el Argentina (1880-2000), 2000, Ediciones Macchi; F. Silvestri, L'Argentina da Perón a Cavallo (1945-2003). Storia economica dell'Argentina dal dopoguerra a oggi, cit., pp. 38 et seq.

3 Banco Central de la Repubblica Argentina, Bullettin of monetary and financial affaire, cit.

${ }^{4}$ By the way, the adoption of the currency board did not prevent the spread among the rates on Argentine bonds (Brady Bonds) and the rate on Americans short-term deposits (Treasury Bond) was maintained at around 400 basis points, showing that the regime fixed exchange rate had a direct effect on the country risk. Both during the Mexican crisis and during the Brazilian one, in fact, the rate spread increased significantly, reflecting the fear that the contagion of these crises could put the Argentine economy in trouble. (BenassI L., Lossani M., Marullo Reedtz P., Le crisi finanziarie internazionali: rischio
} 
Domestic demand could not take a leading role replacing the net foreign demand. Neither household consumption nor business investment could grow at a rate capable of overriding the penalizing outcomes on the aggregate income of the contraction of net foreign demand. In fact, the decline in wage bill, due to the rising unemployment, and the reduction of available income affected consumption. The investments were, instead, affected by the absence of serious prospectives of recovery: the investment rate, ie the ratio of gross fixed investment to GDP, fell from $18 \%$ to $16 \%$ between 1999 and $2001^{1}$.

The new President Fernando De La Rua (1999-2001) received aids from the International Monetary Fund of more than $\$ 7$ billion, to support a three-year economic program (20002003), in which he reaffirmed the basic principles of the convertibility plan, primarily keeping the dollarization of the national economy $(98 \%$ of the debt was denominated in dollars, as well as $60 \%$ of bank deposits at the beginning of the millennium) but also recognizing the need for the country to regain credibility through enhanced fiscal restraint. In order to overcome the ongoing recession, the agenda of the program also included some structural reforms, including that of the labor market, with the aim of creating a more flexible economic environment and increasing the number of employees. The disagreements within the same government majority determined in October 2000 the resignation of the Republic Vice President, Carlos Alvares, as well as an overly restrictive fiscal policy, which involved the further reduction in aggregate demand, making the Argentinian situation unsustainable even for financial market participants and for foreign investors. The risk of abandoning equality became significant, despite the currency board, and interest rates kept rising because of the public deficit expansion. Argentina began to get into debt to pay the interest on the debt, triggering a dangerous spiral of indebtedness which led the ratio of external debt/GDP from 29\% in 1994 to $53 \%$ in $2001^{2}$.

The serious liquidity crisis of the government in the summer of 2001 had consequences on the availability of liquidity for the provinces. From August in various Argentine provinces new means of payment began to appear and, in many cases, the same provincial governments put these systems into circulation to pay salaries. The most famous were the patacones of the province of Buenos Aires, a yearly bond with a coupon of 7\%, equivalent to the peso. From August 21 the patacones began to be distributed for payment of public wages higher than 740 pesos and, to facilitate their acceptance among people, the provincial government allowed their use for the payment of taxes. Other provinces, however, unable to find alternative methods to resolve the crisis, had to declare default. Formosa, one of the poorest provinces, $95 \%$ of whose revenue consisted of transfers fromthe federal government, on August 2 was one of them, forced to the declaration of insolvency on three bonds with a nominal value of

Paese ed effetti sule banche italiane, Associazione per lo sviluppo degli Studi di Banca e Borsa, Quaderno 194, pag. 30).

${ }^{1}$ F. Silvestri, L'Argentina da Perón a Cavallo (1945-2003). Storia economica dell'Argentina dal dopoguerra a oggi, cit., pp. 50 et seq.; cf. Pindea- Garcia S., The Argentinian Crisis, Los Andes University, Bogotà, 2002.

2 «La metástasis financiera y especulativa de la deuda externa asciende a la suma global de 600.000 millones de dolares para America Latina y que para muchos de los países deudores los servicios de la deuda insumen más de la mitad de los saldos exportables. El pago de intereses ya ha superado con cresces lo que los paísess deudores recibieron en concepto de préstamos de capital» ( M. D. Espenche Gil, Intervención, in P. Catalano, edited by, Diritto alla vita e debito estero, Napoli, 1997, Edizioni Scientifiche Italiane, p. 160). 
just over one million dollars. The government, in order to avoid a possible domino effect, decided to advance the transfers and allowed repayment to investors, but the situation of Formosa was a clear sign of the deterioration of the national situation ${ }^{1}$.

A temporary revival of confidence arrived on time, in August, through the new intervention of the IMF, with another loan of $\$ 8$ billion, destined mainly to replenish international reserves of the Central Bank and, again in late August, the IMF paid over 1.2 billion dollars, from a previous credit line ${ }^{2}$.

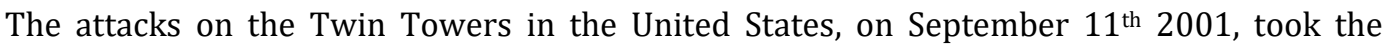
attention of the IMF and the international community away from the Argentine crisis, but, in fact, the crisis had become worse. The recession had resulted in depression. The rate of unemployment according to official statistics had increased to $18 \%$, so that a serious social and institutional crisis was added to the economic and financial crisis. The explosive dynamics of the debt was interrupted in December 2001, when the Argentine government officially declared default, no longer able to face the interest payments. The official announcement came on Dec. $23^{\text {rd }}$ 2001, heralded by a massive capital flight rather than by the rating agencies. The Argentine government declared a moratorium on the debt - \$ 95 billion - by freezing interest payments and by suspending the repayment of maturing capital. The consequences were devastating. In Italy alone there were 450.000 savers in crisis owning the so-called tangobonds amounting to 14.5 billion dollars ${ }^{3}$.

Two days earlier, President De la Rua had resigned and was succeeded by the Peronist Adolfo Rodriguez Saà, replaced a week later by Eduardo Camano, President of the Chamber, who had assumed presidential powers ad interim until the election, in the early days of 2002, of the fifth president, the Peronist Eduardo Duhalde. In order to solve the problem of competitiveness, the currency board was abandoned in January 2002 and the peso was allowed to float freely. The sharp depreciation of the domestic currency determined, however, the collapse of the financial system, because of the pervasive dollarization of debts of the economy (in July 2001, the ratio of deposits in dollars and pesos had reached a value of 1.85, namely the dollar deposits were almost twice that of the deposits in pesos).

Argentina was going through one of the most acute phases of crisis in its history, with a deep recession, high unemployment and a banking sector with a high risk of failure. The peso came back to float on currency markets - after 10 years, on February $11^{\text {th }}$ - recording a loss of about $15 \%$ against the US dollar, together with a sharp decline in the stock market (8.5\%). Within a few weeks, however, the rate of depreciation became more consistent. In mid-March, the pesos exceeded the threshold of 3 units for a dollar. Simultaneously to the return of the pesos fluctuation a new plan for converting active and passive items of banks in pesos was introduced - due to different exchange rates - in order to curb social discontent. The dollar liabilities of banks (mainly represented by deposits) were converted into pesos at the exchange rate of 1,4 to 1 and then indexed to inflation. The dollar assets (loans granted in

\footnotetext{
${ }^{1}$ M. Tommasi, S. Saiegh, P. Sanguinetti, Fiscal federalism in Argentina. Policies, politics and institutional reform, in «Economia: Journal of the Latin American and Caribbean Economic Association», vol. 1, n. 2, 2001, Spring, pp. 157-211.

2 V. Tanzi, M. Blejer, Fiscal policywith high inflation and high debt, in Anales de la Asociación Argentina de Economì Politica, 1985, pp. 1423-1452; cf. V. Tanzi, L'approccio del Fondo monetario internazionale alla riforma fiscale, in «Quaderni di economia e finanza», I, n. 1, 1999.

3 P. Zucca, Argentina, dolori da concambio, in «ll Sole 24 ore», November 1st 2008.
} 
currency) were instead converted into domestic currency at the old convertibility rate of 1 to 1. The "pesification» was a measure that favored those who were indebted in dollars in Argentina and had subsequently transferred the funds abroad, but it strongly penalized banks, which already faced a large loss due to the lower value of the Argentine public debt bonds held in their portfolio, helping to increase the probability that the currency crisis would be accompanied by a true banking crisis ${ }^{1}$.

With the election of President Néstor Kirchner, in 2003, the country was able to restructure the debt in default ${ }^{2}$, although strong doubts about the stability of the national economy remained and were confirmed in the second default of 2014.

Thinking that the problems of Argentina were only due to the exchange rate or to the instability of international financial markets, according to some economists, is at least superficial. The blame for the failure of the country should fall only on the Argentine ruling class, its historic inability to produce a «social contract» that would ensure institutional stability and prudent and forward-looking economic policies. According to others, however, it was the strong defense of the convertibility plan by the government that has perpetuated the overvaluation of the real exchange rate and that prompted the Argentine economy into a deep recession. Finally, some economists have also blamed the IMF for supporting the economic policy of Argentina, by hoping that the crisis was only temporary and only by deciding in late 2001 to suspend the credit line and thus leading the country to a political and monetary regime change. The best time to quit the currency board would probably have been the period immediately following the devaluation of the Real. Argentina, in fact, had come out well from the Asian crisis and the Russian default, but some signs indicated that the stabilization program was running out of its positive effects. It was also the eve of the restrictive monetary policy of the Federal Reserve, so that the Argentine government could have taken the opportunity to untie from the dollar. Unfortunately, in 1999, Argentina was in the middle of an electoral campaign and Peronists could not afford any drastic maneuver. The international community was so prepared for the collapse that it did not have contagious effects on the financial markets, although it was the biggest default in history. Afterwards, Argentina could have officially renounced to the peso and only used the dollar as a means of payment, but it would have meant the country's entry into a monetary union with the United States: monetary

\footnotetext{
${ }^{1}$ Ministry of Economy of the Republic of Argentina, Informe Economico. 41, 2002, cit. in D. A,. Lamanna Di Salvo, Il mercato finanziario argentino: un'analisi macroeconomica della crisi finanziaria del 2002, in «Rivista della Scuola superiore dell'economia e delle finanze», year VII, n. 2, april-september 2010. 2 «State into bankruptcy but interventionist. Economic growth driven by exports and then by the weak peso. Increased public spending with revival of investment in infrastructure. Less emphasis on capital flows from abroad, on the relations with the international community and therefore also on the restructuring of foreign debt. The setting of the government program of the new Argentine President Néstor Kirchner looks like a long list of bad news for the 400,000 and more Italian investors waiting to renegotiate 14 billion euro of Bond. There is a willingness to repay debts, but also a lack of ability. It is not merely a matter of numbers. A political effort on an international scale is needed and without it Argentina will hardly get out of the tunnel alone» (I. Bufacchi, Bond argentini, stallo su Kirchner, in «Il sole 24 ore», 31 may 2003). In January 2003, the relations between the IMF and Argentina had been restarted, and in 2005 the country restructured its debt, causing a more than 70 percent net loss to its creditors. In Italy, there were almost 200,000 savers who did not accept the exchange with shares of different remuneration and currency. In 2006, Buenos Aires repaid \$ 9.5 billion to the Fund (P. Zucca, Argentina, dolori da concambio, cit.).
} 
policy would have been left to the Federal Reserve, meaning that any increase of money in circulation in the United States, would have had similar effects in Argentina through capital flows. According to some economists, the best choice would have been a flexible exchange rate regime, ensuring price stability through a strategy of inflation targeting and the choice of a credible, independent and conservative central banker. ${ }^{1}$

\section{References}

[1] Alberti, G. Castiglione F.M., \& Munini P., Politica Y Ideologia En La Industrializacion Argentina, in «Boletin Informativo Technit», N. 239, 1985.

[2] Banco Central De La Repubblica Argentina, Bullettin of Monetary and Financial Affaire, Publications from the First Trimester 1997 Vol III Trimester 2003, Data at 31st December of Each Year.

[3] Benassi L., Lossani M., \& Marullo Reedtz P., Le Crisi Finanziarie Internazionali: Rischio Paese Ed Effetti Sule Banche Italiane, Associazione Per Lo Sviluppo Degli Studi Di Banca E Borsa, Quaderno 194.

[4] Bianchi P., Sugden R., \& Wilson J. R., the Crisis in Industrial Structure in Argentina: Lessons for Development Policy and Practice, $7^{\text {th }}$ Annual EUNIP (European Network of Industrial Policy), Porto, September, 18-20, 2003.

[5] Bruno M., Di Tella G., Dornbusch R., \& Fischer S., Inflation Stabilization. the Experience of Israel, Argentina, Brazil, Bolivia and Mexico, Boston, 1988.

[6] Bufacchi I., Bond Argentini, Stallo Su Kirchner, in «Il Sole 24 Ore», 31st May 2003.

[7] De Simone E., Storia Economica Dalla Rivoluzione Industriale Alla Rivoluzione Informatica, Milan, 2014.

[8] Diaz Alejandro C., Tipo De Cambio Y Términos Del Intercambio En La Républica Argentina (1913-1976), Work Documents Series N. 22, Centro De Estudios Macroeconómicos De Argentina, 1981.

[9] Economic Commission for Latin America and the Caribbean (Eclac), Strategie Per Una Migliore Integrazione Della Politica Globale, Santiago, 1994.

[10] Edwards T. L., Argentina. a Global Studies Handbook, Santa Barbara, 2008.

[11] Espenche Gil M. D., Intervención, in Catalano P. (Edited by), Diritto Alla Vita E Debito Estero, Napoli, 1997.

[12] Gatto S., America Latina: Il Decennio Cruciale (Cronache D'estremo Occidente), Venezia, 2004.

[13] Ghio J.M., \& Etchhemendy S., the Policy of Administrative Reform in Menem's Argentina, Universidad Torcuato Di Tella, 1997.

\footnotetext{
${ }^{1}$ Cfr. N. Roubini, Should Argentina Dollarize or float? New York University, 2001, Stern School of Business, P. Krugman, Notes on depreciation, the yen and the argentino, in «Central Banking Journal», vol, XII, n. 3; Shuler Kurt, Hanke Steve, How to dollarize in Argentina now, Cato Institute, 2001.
} 
[14] Hanke Steve H., \& Schule R K., Currency Board for Developing Countries: a Handbook, 2000.

[15] Infranca a., Argentina, Modello Di Neoliberismo, in «Critica Marxista», Nuova Serie, N. 3/4, May-August 2000.

[16] Kaminsky G., Lizondo S., \& Reinhart C., Leading Indicators of Currency Crisis, International Monetary Fund Staff Papers, 1998, Vol. 45, N. 1.

[17] Kosacoff B., Corporate Strategies Under Structural Adjustment in Argentina, London, 2000.

[18] Kosacoff B., El Desafio De La Competitividad. La Industria Argentina En Trasformatcìon, Buenos Aires, 1993.

[19] Krugman P., Notes on Depreciation, the Yen and the Argentino, in «Central Banking Journal», Vol, XII , N. 3

[20] Lamanna Di Salvo D., Il Mercato Finanziario Argentino: Un'analisi Macroeconomica Della Crisi Finanziaria Del 2002, in «Rivista Della Scuola Superiore Dell'economia E Delle Finanze», Year VII, N. 2, April-September 2010.

[21] Novaro M., \& Palermo V., Politica Y Poder En El Gobierno De Mennen, Buenos Aires, 1997.

[22] O’Donnel G., El Estrado Burocratico Autoritario, Buenos Aires, 1982.

[23] Pindea Garcia S., the Argentinian Crisis, Bogotà, 2002.

[24] Portantiero J.C., Clases Dominantes Y Crisis Politica En La Argentina Actual, Buenos Aires, 2003.

[25] Rapoport M. Y Collaboradores, Historia Econòmica, Pòlitica Y Social De El Argentina (1880-2000), 2000.

[26] Rock D., Argentina 1516 - 1987. from Spanish Colonization to Alfonsín, Los Angeles, 1985.

[27] Roubini N., Should Argentina Dollarize or Float? New York, 2001.

[28] Shuler K., \& Hanke S., How to Dollarize in Argentina Now, Washington, 2001.

[29] Silvestri F., L’Argentina Da Perón a Cavallo (1945-2003). Storia Economica Dell'argentina Dal Dopoguerra a Oggi, Bologna, 2004.

[30] Stiglitz J. E., Etica, Politica Economica E Paesi in Via Di Sviluppo, in L. Ornaghi, (Edited by), Globalizzazione: Nuove Ricchezze E Nuove Povertà, Milan, 2001.

[31] Sturzenegger a. -Moya R., Economic Cycles, in G. Della Paolera - a.M. Taylor (Edited by), a New Economic History of Argentina, Cambridge, 2003.

[32] Sylos Labini P., El Plan Austral Y La Politica Argentina: Algunas Reflexiones, Buenos Aires, 1987.

[33] Tanzi V., \& Blejer M., Fiscal Policywith High Inflation and High Debt, in Anales De La Asociación Argentina De Economìa Politica, 1985. 
[34] Tanzi V., L'approccio Del Fondo Monetario Internazionale Alla Riforma Fiscale, in «Quaderni Di Economia E Finanza», I, N. 1, 1999.

[35] Tedesco L., Democracy in Argentina. Hope and Disillusion., New York, 1999.

[36] Tommasi M., Saiegh S., \& Sanguinetti P., Fiscal Federalism in Argentina. Policies, Politics and Institutional Reform, in «Economia: Journal of the Latin American and Caribbean Economic Association», Vol. 1, N. 2, 2001.

[37] Zucca P., Argentina, Dolori Da Concambio, In «Il Sole 24 Ore», November 1st 2008.

\section{Websites:}

www.mecon.gov.ar (Argentine Ministry of Economy). 